\title{
Análise de fraturas supracondilianas do úmero em crianças
}

\author{
Analysis of supracondylares Fractures \\ of the Humerus in Children
}

\begin{abstract}
Rodrigo Klafke MartinI ${ }^{1}$, Gisele Finkler da Fonseca ${ }^{1}$, Rafael KLAfKe MartinI', Mauro Azeredo Filho ${ }^{2}$, Osvaldo André Serafin ${ }^{3}$
\end{abstract}

\section{RESUMO}

Os autores realizaram um levantamento retrospectivo dos atendimentos de crianças com fratura supracondiliana do úmero, com o objetivo de analisar as características deste tipo de fratura, e comparar com a literatura. Foram revistos fichas e prontuários de pacientes atendidos no serviço de Traumatologia e Ortopedia do Hospital São Lucas da PUCRS que preencheram todos os dados do levantamento: idade, raça, lado acometido, classificação da fratura, complicações e tratamento.

Os resultados encontrados são de 63 pacientes numa população que variou de 1 ano a 11 anos de idade. Lesões em extensão e flexão ocorreram em 78,5\% e 10,5\% dos casos, respectivamente. Houve predomínio do sexo masculino $(63,4 \%)$ e da raça branca $(95,2 \%)$. O lado esquerdo foi o mais acometido, em 55,6\% dos casos. Foi realizado tratamento cirúrgico em 76\% e conservador em 24\%. Quanto a classificação de Gartland, encontrou-se 8\% do tipo I, $17,4 \%$ do tipo II, e $74,6 \%$ do tipo III. Observou-se ainda complicações nervosas em 6,35\% dos casos, enquanto complicações vasculares ocorreram em $3,2 \%$. Os resultados obtidos vão ao encontro dos dados descritos na literatura, constatando a importância desta patologia em crianças e a necessidade de conhecimento das características, classificação e manejo dessa patologia.

Descritores: Fratura supracondiliana; úmero; trauma pediátrico; fratura de cotovelo.

\section{INTRODUÇÃO}

Os autores fazem uma breve revisão das fraturas supracondilianas do úmero em crianças, associando a isso um levantamento dos casos atendidos no Hospital São Lucas da PUC-RS com o objetivo de estratificar as características de apresentação e de tratamento dessas fraturas e compará-las com os dados encontrados na literatura.

\section{SUMMARY}

The authors made a retrospective review of children with supracondylar fracture of the humerus with the purpose of analyzing these fractures characteristics and comparing them with the literature. The registers from patients attended at the Trauma and Orthopedics Service, São Lucas Hospital, PUCRS, containing the data necessary for the survey (age, race, affected side, fracture classification, complications and treatment) were reviewed.

Sixty-three 1 to 11 year-old patients were studied. Extension and flexion lesions occurred in $78.5 \%$ and $10.5 \%$ of the cases, respectively. Most of the cases were observed in males (63.4\%) and whites (95.2\%). Lesions at the left side (55.6\%) were more frequent. Surgical treatment was carried out in $76 \%$ of the cases and conservative treatment in $24 \%$. As concerns the Gartland Classification, $8 \%$ were type 1, 17,4\% type II, and 74,6\% type III. Nerve complications were observed in $6.35 \%$ of the cases, and vascular complications in $3.2 \%$. The results of the survey are consistent with the literature outlining the importance of this pathology in children and the need of acknowledging the characteristics, the classification, and the management of this pathology.

Key Words: supracondylar fracture, humerus, pediatric trauma, elbow fracture.

\section{INTRODUCTION}

The authors reviewed the supracondylar fractures of the humerus in children, associating the findings to cases attended at the São Lucas Hospital, PUCRS. The aim of the study was to stratify the characteristics of presentation and treatment of these fractures and compare them to data found in the literature.
Trabalho realizado na Faculdade de Medicina da Pontifícia Universidade Católica do Rio Grande do Sul (PUCRS) Serviço de Traumatologia e Ortopedia do Hospital São Lucas.

\section{1- Acadêmicos de Medicina}

2- Médico Ortopedista

3- Professor Doutor

Endereço para correspondência: Rodrigo Klafke Martini - Caixa Postal 047 CEP 94400-970 - Viamão - RS - Brasil

E-mail: rodrigomartini@hotmail.com
*Work performed at the College of Medicine, PUCRS - Trauma and Orthopedics Service, São Lucas Hospital.

1- Medical Student

2- Orthopedic Surgeon

3- PhD Professor

Address: Rodrigo Klafke Martini - Caixa Postal 047

CEP 94400-970 - Viamão - RS - Brasil

E-mail: rodrigomartini@hotmail.com

Trabalho recebido em 09/08/2001. Aprovado em 28/03/2002 
As fraturas distais do úmero, situadas logo acima dos condilos, correspondem às chamadas fraturas supracondilianas. Esse tipo de lesão é uma das mais comuns em crianças, ocorrendo raramente em adultos ${ }^{(6)}$

As fraturas supracondilianas são divididas em 2 tipos conforme a posição do cotovelo no momento do trauma: fraturas em extensão ou em flexão. As em extensão acontecem após queda para frente, com o apoio da mão, seguida de hiperextensão do cotovelo e correspondem a grande maioria das lesões, sendo descritas em até $95 \%$ dos $\operatorname{casos}^{(8)}$. Vasos sangüíneos e nervos dessa região podem ser contundidos, comprimidos, ou até mesmo lacerados por fragmentos ósseos. Por essa razão, não é recomendado palpar ou mobilizar a fratura para o diagnóstico, pois tal procedimento acarreta riscos às estruturas neuro-vasculares da região do cotovelo ${ }^{(4)}$. A realização de radiografias ântero-posteriores e perfil do cotovelo são obrigatórias para visualização da fratura, avaliação do grau de deslocamento, rotação e desvios dos ossos, assim como para identificação de possíveis fragmentos ósseos. Fraturas em flexão ocorrem de 5 a 10\% ${ }^{(8)}$. Quedas ao solo com o cotovelo fletido, e impacto nessa posição é a maneira mais usual desse tipo de fratura ${ }^{(4)}$.

Como conseqüência das fraturas supracondilianas, poderá haver o comprometimento de estruturas neuro-vasculares da região, dependendo da intensidade e do tipo de trauma. A lesão da artéria braquial é relativamente freqüente nos casos de fratura do tipo III, sendo a alteração vascular mais comum nesse tipo de trauma. Ocorre por compressão ou ruptura da mesma devido a um fragmento ósseo, podendo provocar déficit circulatório no antebraço e mão. Nos casos de compressão da artéria a descompressão deve ser considerada uma emergência, pois após algumas horas os danos podem ser irreversíveis ${ }^{(6)}$. A lesão do nervo radial é a alteração nervosa mais comum, embora o deslocamento póstero-lateral também possa provocar lesões na artéria braquial e nervo mediano. O exame neurológico do ponto de vista motor deve ser realizado com cautela, a fim de detectar possíveis alterações nervosas que podem ser temporárias ou permanentes.

\section{MATERIAL E MÉTODOS}

A classificação de Gartland, devido a sua utilidade para diagnóstico, implica diretamente na forma de tratamento, classificando as fraturas em extensão em 3 tipos ${ }^{(2,7)}$. No entanto, as fraturas em flexão
B

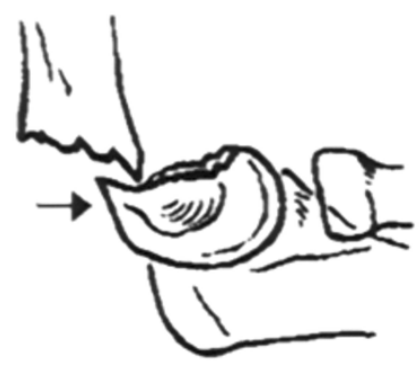

The distal fractures of the humerus, just above the condyles, correspond to the so called supracondylar fractures. This kind of lesion is one of the most common in children, however, seldom it occurs in adults(6).

The supracondylar fractures are classified in two types according to the elbow posi-
or flexion fractures. The extension fractures occur after frontal fall supported by the hand, followed by hyperextension of the elbow, and they correspond to the majority of the lesions, occurring in up to $95 \%$ of the cases ${ }^{(8)}$. Blood vessels and nerves of this region can be injured, compressed or even lacerated by bone fragments. Considering this, it is not recommended to palpate or mobilize the fracture to make the diagnosis, since this can put into risk the neuro-vascular structures of the elbow ${ }^{(4)}$. Anterior-posterior X-rays and elbow profile are compulsory to visualize the fracture, to evaluate the degree of displacement, rotation and deviation of the bones, as well as to identify possible bone fragments. Flexion fractures occur in $5-10 \%$ of the cases ${ }^{(8)}$. Falls and impacts with a bent elbow are the most common cause of this kind of fracture ${ }^{(4)}$.

As a consequence of the supracondylar fractures, the neuro-vascular structures can be compromised, depending on the intensity and kind of the trauma. The brachial artery lesion is relatively frequent in the type III kind of fracture, and vascular alteration is more common in that kind of trauma. It occurs due to compression or rupture caused by a bone fragment, and may provoke circulatory deficit in the forearm and hand. In the cases of compression of the artery, decompression must be considered an emergency, since after a few hours the damage can be irreversible ${ }^{(6)}$. The radial nerve lesion is the most common alteration, though the posteriorlateral displacement can also cause lesions to the brachial artery and median nerve. The neurological exam considering the motor aspect must be performed with precaution, to detect transient or permanent nerve alterations.

\section{MATERIAL AND METHODS}

The Gartland Classification, a useful diagnostic tool, implies directly in the form of treatment, classifying the extension fractures in 3 types ${ }^{(2,7)}$. Notwithstanding, the flexion fractures also can 
também podem ser classificadas quanto aos critérios de Gartland(8):

Tipo I: embora haja fratura supracondilar, o deslocamento inexiste ou é mínimo; a fratura pode ser visualizada em radiografias oblíquas;

Tipo II: embora a fratura tenha deslocamento posterior, a integridade posterior da córtex óssea está preservada; é necessário considerar radiografias contralaterais para ajudar a determinar a anatomia normal do cotovelo.

Tipo III: existe deslocamento e interrupção na córtex posterior do osso com perda do contato cortical entre os fragmentos. O fragmento distal é deslocado posteriormente e proximalmente pela contração do tríceps nas fraturas em extensão. Já nas fraturas em flexão o deslocamento do fragmento distal ocorre para frente (Figura 1) ${ }^{(4)}$. Nas radiografias em AP o deslocamento pode ser póstero-lateral ou póstero-medial; a rotação do fragmento distal também deve ser considerada, embora possa ser difícil de determinar. Nestes casos a tomografia computadorizada pode ser de grande ajuda, mas normalmente não é realizada na urgência.

Foram revistos fichas e prontuários de pacientes entre 1 ano 11 anos de idade atendidos no Serviço de Traumatologia e Ortopedia do HSL-PUCRS, perfazendo um total de 97 casos de crianças com fratura supracondiliana do úmero. Destes, 34 foram excluídos por apresentarem dados insuficientes ou déficit de exames radiológicos para que se pudesse classificar o tipo de fratura. Assim, os autores levaram em consideração a idade do paciente, sexo, raça, membro acometido pelo trauma, classificação da fratura, complicações neuro-vasculares, bem como o seu tratamento (cirúrgico ou conservador), de acordo com a classificação proposta por Gartland. Quanto ao tratamento cirúrgico, também foi verificada a quantidade e posição dos pinos; e quando conservador se foi necessária ou não a redução da fratura. Foram então levantados 63 pacientes que satisfizeram todas as condições acima listadas, sendo posteriormente analisadas e projetadas em estatísticas, servindo como objeto de estudo para este trabalho.

\section{RESULTADOS}

Os resultados apontaram que em uma amostra de 63 pacientes com fraturas supracondilianas de idades entre 1 e 11 anos, a idade média foi de 6,2 anos. Estima-se estatisticamente que a idade média esteja compreendida no intervalo de 5,7 a 6,9 anos, com 95\% de segurança. Houve prevalência de indivíduos do sexo masculino, 63,4\% dos pacientes, e da raça branca, 95,2\%. Em relação ao membro traumatizado, tem-se um moderado predomínio do lado esquerdo, acometendo $55,6 \%$ dos pacientes analisados. Conforme a classificação de Gartland, foi encontrado 8\% do tipo I, 17,4\% do tipo II e 74,6\% do tipo III. Em 89\% das fraturas houve deslocamento. De todos os casos com desvio, 78,5\% ocorreram nas fraturas em extensão. Destas, o deslocamento foi póstero-medial em $37,5 \%$ dos casos, póstero-lateral em $30,3 \%$ e, posterior em 10,7\%.

Nos casos em que houve fraturas em flexão, essas somam $10,5 \%$ do total de casos com deslocamento, possuindo desvios ântero-mediais em 5,3\%, anteriores em 3,5\%, e ântero-laterais em $1,7 \%$ dos casos. Foram ainda vistos casos sem desvios anteriores ou posteriores, tendo apenas desvio medial, em be classified according to the Gartland criteria(8) $^{(8)}$

Type 1: although a supracondylar fracture, displacement is absent or minimum; the fractures can be visualized in oblique $X$-rays.

Type II: although the fracture presents posterior displacement, the posterior integrity of the bone cortex is preserved; it is necessary to consider contralateral X-rays to determine the normal anatomy of the elbow.

Type III: displacement and discontinuity of the bone posterior cortex are present with loss of cortical contact between the fragments. The distal fragment is posteriorly and proximally displaced by the triceps contraction in the extension fractures. In the flexion fractures the distal fragment displacement occurs forwardly (Figure 1) ${ }^{(4)}$. In the AP X-rays the displacement can be posterior-lateral or posterior-medial; the distal fragment rotation also must be considered, though difficult to determine. In these cases, computerized tomography can be of great help, but it usually is not ordered in emergency attendances.

The registers of one to eleven year-old patients attended in the Trauma and Orthopedics Service of the São Lucas Hospital, PUCRS, were reviewed summing up 97 cases of children with supracondylar fracture of the humerus. Among these, 34 were excluded since the data or radiological exams were insufficient to determine the kind of fracture. The authors considered age, sex, race, affected limb, fracture classification, neurovascular complications, as well as treatment (surgical or conservative) according to the classification proposed by Gartland. Considering surgical treatment, the quantity and position of the pins were determined; considering the conservative treatment, the need to reduce or not the fracture was considered. Sixty-three patients who met the above mentioned statistically analyzed conditions were the subject of this study.

\section{RESULTS}

The results have shown that in a sample of 63 patients with supracondylar fractures aged 1 to 11 years the mean age was 6.2 years. Statistically, the mean age is between 5.7 and 6.9 years, with $95 \%$ confidence. Males (63.4\%) and whites (95.2\%) predominate. Considering the affected limb, the left side showed moderate predominance (55.6\%). According to the Gartland Classification, type I was found in $8 \%$, type II in $17.4 \%$ and type III in $74.6 \%$ of the cases. Displacement was observed in $89 \%$ of the fractures. Among the cases with deviation, $78.5 \%$ were extension fractures. Among these, displacement was posterior-medial in $37.5 \%$ of the cases, posterior-lateral in 30.3\%, and posterior in $10.7 \%$.

In the cases with flexion fractures, these represent $10.5 \%$ of the cases with displacement, with anterior-medial deviation in $5.3 \%$, anterior in $3.5 \%$, anterior-lateral in $1.7 \%$ of the cases. Cases with no anterior or posterior deviations were observed, presenting medial deviation in $7.1 \%$ and lateral in $3.5 \%$ of the cases.

As concerns treatment, surgical intervention was the tre- 
$7,1 \%$, e laterais em $3,5 \%$ dos casos.

Quanto ao tratamento, a intervenção cirúrgica foi o tratamento de escolha na grande maioria, totalizando 76\%. Destes, em 48\% foram colocados 2 pinos cruzados, em $48 \%$ foram utilizados 2 pinos laterais e paralelos, em $2 \%$ se utilizou 3 pinos cruzados (2 laterais e 1 medial) e nos $2 \%$ restantes os 2 pinos foram mediais. Foi realizado tratamento conservador em $24 \%$ dos 63 pacientes estudados, necessitando de redução em $66,6 \%$.

Os resultados do levantamento retrospectivo de prontuários dos pacientes foram submetidos à análise estatística descritiva, com estimação por intervalo, tendo sido utilizado o teste do qui-quadrado de aderência. Demonstrou-se estatisticamente diferença significativa para todos os itens levantados, com $p \leq 0,05$ e com 95\% de segurança. Apenas quanto ao lado acometido não houve diferença significativa, com a incidência podendo ser casual $(p=0,377)$.

Observou-se complicações nervosas em 6,35\% dos casos, todos comprometendo o nervo mediano, enquanto complicações vasculares ocorreram em 3,2\% da amostra. Quando comparados com dados da literatura, 7,6 e 3,3\% respectivamente, o teste para uma proporção de aderência demonstrou não haver diferença estatística significativa com os dados da literatura $(p=0,711)$.

\section{DISCUSSÃO}

A fratura supracondiliana do úmero é a mais importante na infância, constituindo de 52,3 a 69\% das fraturas do cotovelo nessa faixa etária ${ }^{(5)}$. Ocorre mais comumente em meninos, principalmente entre os 3 e 10 anos de idade, com maior freqüência entre os 4 e 7 anos de idade (pico: 6,5 anos) ${ }^{(1,5,6)}$. Assim, a literatura confirma os achados em relação à prevalência do sexo masculino, idade média e lado acometido encontrados nos casos levantados. No entanto, não foi encontrado pelos autores referência quanto à prevalência de raça na bibliografia consultada.

Devido aos mecanismos da fratura nos casos de trauma em extensão, que chegam a 95\% dos casos, o apoio da parte distal do úmero no rádio e na ulna levam a um traço da fratura na região supracondiliana do úmero; se houver desvio, ela será posterior primariamente, sendo descritos até em $94 \%$ dos casos na literatura ${ }^{(1)}$. 0 fragmento distal é deslocado posteriormente e medialmente, isso porque o antebraço se encontra, geralmente, em pronação completa ${ }^{(1,3)}$. Destes, a prevalência se dá com rotação medial ou lateral associada ao desvio posterior. Esses dados da literatura também confirmam os achados dos autores, onde os desvios posteriores foram encontrados em $78,5 \%$ dos casos levantados, sendo $10,7 \%$ apenas posterior, 37,5\% póstero-medial e 30,3\% póstero-lateral. Se, ao con- atment of choice in most cases (76\%). In $48 \%$ crossed pins were placed, $48 \%$ received lateral and parallel pins, $2 \%$ received 3 crossed pins (2 lateral and 1 medial) and in the remaining $2 \%$ the pins were medial. Conservative treatment was effected in $24 \%$ of the 63 studied patients, demanding reduction in $66.6 \%$.

The results of the retrospective survey of the patients registers were submitted to descriptive statistical analysis, with estimation by interval, using the chi-square test of adherence. Statistically significant difference was observed in all items, with $p \leq 0.05$ and 95\% confidence. No significant difference was found in the affected side, the incidence being casual ( $p=0.377$ ).

Nerve complications were found in $6.35 \%$ of the cases, all of them affecting the median nerve; vascular complications were observed in $3.2 \%$ of the sample. When compared with the scientific literature, $7.6 \%$ and $3.3 \%$, respectively, the test for a proportion of adherence did not present a statistically significant difference $(p=0.711)$.

\section{DISCUSSION}

The supracondylar fracture of the humerus is mostly found in children, summing up 52.3 to $69 \%$ of the elbow fractures ${ }^{(5)}$. It is more frequently observed in 3 to 10 year-old boys, more frequently between 4 and 7 years (peak: 6.5 years) ${ }^{(1,5,6)}$. The literature confirms the findings as concerns prevalence of males, mean age and affected side in the surveyed cases. However, the authors did not find references related to the prevalence of race in the literature.

Due to the fracture mechanisms in the cases of extension trauma, 95\% of the cases, the support of the distal part of the humerus in the radius and ulna leads to a fracture in the supracondylar region of the humerus; if there is deviation, it will be primarily posterior, occurring in up to $94 \%$ of the cases mentioned in the literature ${ }^{(1)}$. The distal fragment is posteriorly and medially displaced, because the forearm is, in general, in complete pronation ${ }^{(1,3)}$. Prevalence occurs with medial or lateral rotation associated to posterior deviation. These data from the literature also confirm the authors' findings where the posterior deviations were found in $78.5 \%$ of the surveyed cases, $10.7 \%$ only posterior, $37.5 \%$ posterior-medial and $30.3 \%$ posterior-lateral. If, on the contrary, the mechanism occurs in flexion, the primary deviation will be anterior, the fall over the hand with the elbow in straight position ${ }^{(1,3)}$. This lesion occurred in $10.5 \%$ of the studied cases; in the literature, 
trário, o mecanismo ocorre em flexão, o desvio primário será anterior, com a queda sobre a mão e com o cotovelo reto ${ }^{(1,3)}$. Esta lesão ocorreu em $10,5 \%$ dos casos pesquisados, aproximando-se dos dados da literatura, onde esse tipo de trauma perfaz $6 \%$ das fraturas supracondilianas de úmero. Em 85,4\% dos nossos pacientes foram observados alguns graus de rotação. A literatura refere $63 \%{ }^{(1)}$.

O desvio em valgo foi encontrado em $49,9 \%$ e em varo em $35,5 \%$ dos pacientes, comparados a $40 \%$ e $36 \%$ encontrados na literatura, respectivamente. Tanto desvios rotacionais em valgo, como em varo, devem ser corrigidos, pois mesmo com o crescimento, tais desvios não retornam a sua forma anatômica ${ }^{(1)}$.

Ainda nos traumatismos do cotovelo pode haver danos vasculares importantes devido ao grande aporte vascular da região. Assim, o edema e a equimose resultantes podem ser consideráveis, pois a fratura provoca um grande hematoma que visto após 24 horas da ocorrência se traduz por uma equimose linear na prega anterior do cotovelo, conhecida como sinal de Kirmissom ${ }^{(1)}$. Conforme a intensidade de tal hematoma e conseqüente edema, a manipulação da área torna-se difícil após 12 horas de evolução.

Nos casos de fraturas graves onde o osso é fragmentado numa porção proximal e outra distal, deve-se ficar atendo para possíveis lesões de músculos, nervos ou vasos. Se a porção distal for desviada posteriormente, a ponta da porção proximal pode romper o músculo braquial. Já se houver desvio medial da porção proximal, o nervo radial pode também ser lesionado. Nos casos de desvios laterais, a ponta do fragmento proximal pode lesar o nervo mediano e/ou a artéria braquial ${ }^{(1)}$. A literatura refere uma média de $7,6 \%{ }^{(1,5)}$ de casos de lesões nervosas, e 3,3\% ${ }^{6}$ de lesões vasculares, sendo bastante semelhantes àquelas encontradas pelos autores, 6,3\% e 3,2\%, respectivamente.

Quanto ao tratamento cirúrgico ter sido realizado em $76 \%$ dos casos, devemos considerar que como o tipo II de fratura possui uma cortical óssea posterior intacta com estabilidade mantida, é considerado o uso de 2 pinos laterais. Os pinos podem ser utilizados em paralelo ou cruzados próximo ao local da fratura. Assim, de forma paralela, não há risco de lesão do nervo ulnar, que constitui uma complicação do tratamento cirúrgico ${ }^{(8)}$. No tipo III de fratura, o tratamento se assemelha ao das fraturas do tipo II quando essas necessitam de cirurgia. No entanto, a maior probabilidade de lesões neuro-vasculares nas fraturas com descontinuidade da cortical faz com que o procedimento cirúrgico seja quase obrigatório em todos os casos de fratura tipo III. Para o tratamento, a redução e a fixação percutânea com dois fios de Kirschner cruzados constitui o tratamento de escolha, sendo realizado em $48 \%$ dos casos levantados (Figuras 2,3,4,5). Para evitar this kind of trauma occurred in $6 \%$ of the supracondylar fractures of the humerus. In $85.4 \%$ of our patients some degree of rotation was observed. Literature mentions $63 \%{ }^{(1)}$.

Valgus deviation was found in $49.9 \%$ and varus in $35.5 \%$ of the patients, as compared to $40 \%$ and $36 \%$ found in the literature, respectively. Both rotational deviations in valgus and in varus must be corrected, since even during growth these deviations do not resume their anatomical shape ${ }^{(1)}$.

In traumas of the elbow, important vascular damages can occur due to the vascular volume in this region. Thus, edema and echymosis can be considerable, since the fracture 24 hours after the accident promotes a big hematoma showing a linear echymosis in the anterior fold of the elbow, known as the Kirmissom signal(1). Depending on the intensity of this hematoma and consequent edema, manipulation of the area becomes difficult after 12 hours.

In the cases of severe fractures when the bone is fragmented in proximal and distal sites, attention must be paid to possible lesions in the muscles, nerves or vessels. If the distal portion was posteriorly deviated, the tip of the proximal portion can cause rupture of the brachial muscle. If medial deviation occurs in the proximal portion, the radial nerve can also be lesioned. In cases of lateral deviation, the tip of the proximal fragment can lesion the median nerve and/or the brachial artery ${ }^{(1)}$. The literature ${ }^{(1,5)}$ mentions on average ${ }^{(1,5)} 7.6 \%$ cases of nerve lesions, 3.3\% of vascular lesions, values very similar to those found by the authors, 6.3 and 3.2\%, respectively.

Considering that surgical treatment was effected in $76 \%$ of the cases, we must mention that as in fracture type // the posterior bone cortical is intact with mantained stability, the use of 2 lateral pins is considered. The pins can be used in parallel or crossed close to the fracture. Thus, in parallel, there is no risk of lesion to the ulnar nerve, a complication of the surgical treatment ${ }^{(8)}$. In fracture type III, treatment is similar to type II fractures when surgery is necessary. However, the greater probability of neurovascular lesions in the fractures with discontinuity of the cortical demands almost compulsory surgical procedures in all cases of type III fracture. The treatment of choice is reduction and percutaneous fixation with two threads of Kirschner crossed, and it is carried out in $48 \%$ of the surveyed cases (Figures 2,3,4,5). To avoid the risk of ulnar nerve lesion, 2 pins can also be used by the side of the lateral epycondile, also crossing the fracture, going in the direction and perforating the opposite proximal cortical(8). 


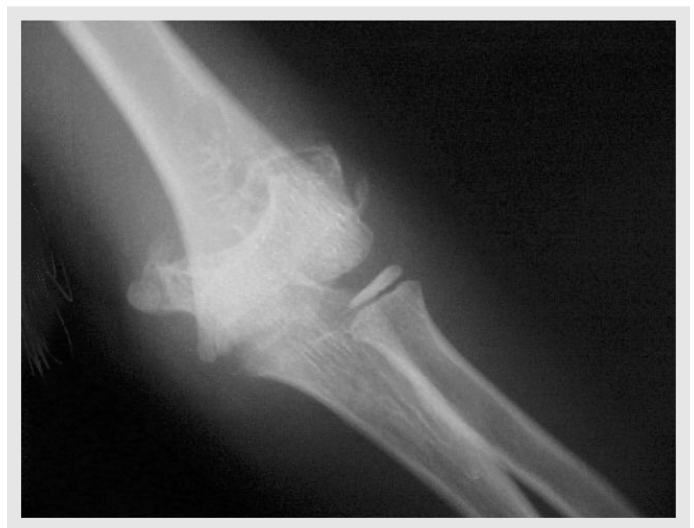

Figura 3 - Raio $X-A P$.

Figure 3 - X-Rays - AP.

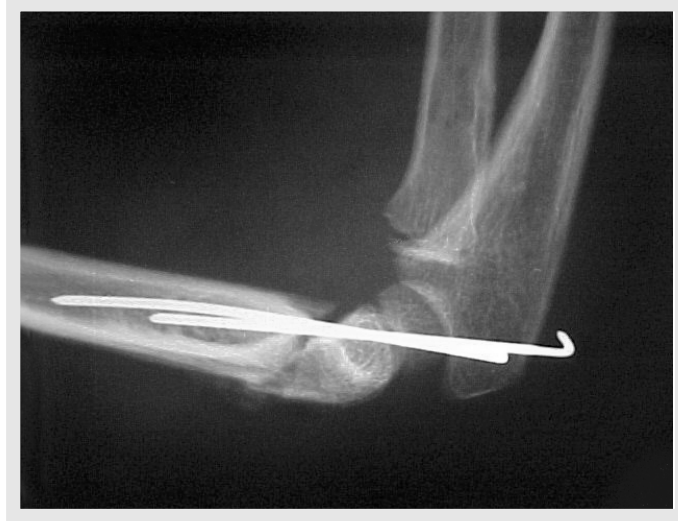

Figura 4 - Raio X - Perfil - Pós-operatório imediato com 2 fios de Kirschner cruzados.

Figure 4 - X-Rays - Profile - Immediate postoperative with 2 Kirschner Crossed threads. o risco de lesão do nervo ulnar, também pode ser utilizado 2 pinos pelo lado do epicôndilo lateral, que também cruzam a fratura, indo em direção e perfurando a cortical proximal oposta ${ }^{(8)}$.

\section{CONCLUSÃO}

Os resultados obtidos com o levantamento das características das fraturas supracondiliana de úmero de crianças no Hospital São Lucas da PUCRS confirmam os dados da literatura pesquisada. Assim, o conhecimento desse tipo de fratura e suas peculiaridades, como idade, sexo e membro em que mais freqüentemente ocorrem, apresentam importância não apenas para traumatologistas e ortopedistas, como também para médicos ligados a serviços de primeiro atendimento. Devido à elevada freqüência de traumatismos em cotovelo e, conseqüentemente, o elevado número de fraturas supracondilianas do úmero, o manejo inicial com base na classificação de Gartland, proporciona maior segurança para um tratamento eficaz e com menor risco de deformidades posteriores, principalmente devido a complicações neuro-musculares relacionadas a esse tipo de fratura.

\section{REFERÊNCIAS BIBLIOGRÁFICAS}

1. Adams, J.C., Hamblen D.L.: Manual de Fraturas, $10^{a}$ ed., Porto Alegre, Artes Médicas, 1994, p. 140-44.

2. Apley, A.G.: Manual de Ortopedia e Fraturas, Rio de Janeiro, Atheneu, 1989, p. 405-08.

3. Gartland, J.J.: Management of Supracondylar Fractures of the Humerus in Children.Surg. Gynecol. Obstet. 109: 145-54, 1959.

4. Herbert, S., Xavier R., Jr. A.G.P. et al.: Ortopedia e Traumatologia. Princípios e Prática, $2^{\mathrm{a}}$ ed. Porto Alegre, Artes Médicas, 1998, p. 514-19.

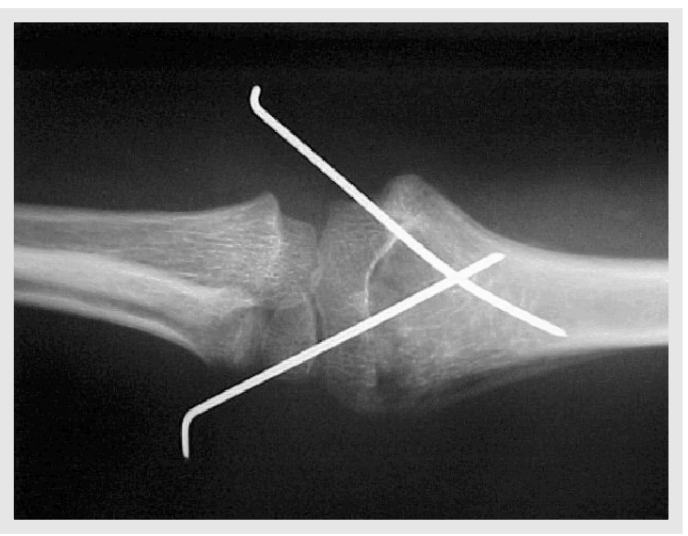

Figura 5 - Raio $X$ - AP - Pós-operatório imediato.

Figure 5 - X-Rays - $A P$ - Immediate post-operative.

\section{CONCLUSION}

The results of surveying the characteristics of the supracondylar fractures of the humerus in children in the São Lucas Hospital, PUCRS, confirm the data found in the literature. The knowledge of that kind of fracture and its peculiarities, as age, sex and affected limb, is important not only for the traumatologists and orthopedists but also for the doctors who work in the emergency services. Due to the high frequency of trauma in the elbow and, consequently, the high number of supracondylar fractures of the humerus, the initial procedures according to the Gartland Classification provide more certainty of an effective treatment with less risk of future deformities mainly due to the neuromuscular complications related to that kind of fracture.

5. Howard, S. Manual do Residente em Ortopedia, Rio de Janeiro, Revinter, 1995, p. 196-97.

6. Nasi, L.A. e Colaboradores: Rotinas em Pronto Socorro: politraumatizados e emergências ambulatoriais, Porto Alegre, Artes Médicas, 1994, p. 229-33.

7. Rockwood, C.A., Wilkins K.E., King R.E.: "Fraturas e Luxações da Região do Cotovelo" in Fraturas em Crianças, $1^{\text {a }}$ ed. Brasileira. Volume 1, Editora Manole, 1993, p. 497-808.

8. Wheless C.R., Wheeless' Textbook of Orthopaedics, 1996. (http://www.medmedia.com/orthoo/91.htm). 